\title{
UNDERGROUND CHAMBER SYSTEMS EXCAVATED BY CENOZOIC GROUND SLOTHS IN THE STATE OF RIO GRANDE DO SUL, BRAZIL
}

\author{
HEINRICH THEODOR FRANK, CAMILA ELIZA ALTHAUS, ERIK MARTINS DARIO, \\ FERNANDO RUBBO TRAMONTINA, RAFAEL MARQUEZAM ADRIANO, \\ MARIANA DE LIMA ALMEIDA
}

Instituto de Geociências, Universidade Federal do Rio Grande do Sul, Cx. P. 15001, Av. Bento Gonçalves, 9500, 92501-970, Porto Alegre, RS, Brasil.heinrich.frank@ufrgs.br, camilaalthaus@gmail.com,erikdario@hotmail.com, tramontinarubbo@hotmail.com, rafa2005adriano@hotmail.com, mary_lima_almeida@hotmail.com

\author{
GABRIELA FEITEN FERREIRA, RAFAELA NOGUEIRA \& ROGÉRIO BREIER \\ Universidade do Vale do Rio dos Sinos, Av. Unisinos, 950, 93022-000, São Leopoldo, RS, Brasil. \\ gabriele.paleotocas@gmail.com, rafaela.paleotocas@gmail.com,rbreier@via-rs.net
}

\begin{abstract}
A regional survey of the caves of the state of Rio Grande do Sul, Brazil, listed hundreds of caves with varied origins. Among these, we identified two large caves with special characteristics, one located in the city of Santa Cruz do Sul and the other in the municipality of Vale Real. Both evolve in an approximately horizontal plane, extend tens of meters into the interior of the respective elevations, and do not show any signs of present or past underground drainage. Concave surfaces on the walls stand out in their morphologies, which suggest that the caves originally constituted a system of ellipsoidal chambers, each chamber with original height of approximately $1.5 \mathrm{~m}$ and diameter between 3.5 and $7 \mathrm{~m}$. The individual chambers were connected by relatively short tunnels. These chambers are best preserved in the cave of Santa Cruz do Sul; the cave of Vale Real appears to have been much disfigured, both because of inorganic processes and anthropogenic action. The general characteristics of these two caves enable us to propose that they originated from the activity of digging ground sloths of the South American Megafauna. Their dimensions suggest that they were excavated and inhabited not by individual animals, but by groups of sloths. The original polished walls suggest that the caves were used for extended periods, possibly in the order of centuries. Their morphology is so different from other tunnel systems that were excavated by the Megafauna and found in southern Brazil, that we suggest that this morphology of chamber systems is associated with a specific species of ground sloth, whose identification will be very difficult.
\end{abstract}

Key words: caves, megafauna, ground sloths, tunnels, chambers, Brazil.

RESUMO - Um levantamento regional das cavernas existentes no estado do Rio Grande do Sul, Brasil, listou centenas de cavernas com variadas origens. Dentre estas, foram identificadas duas cavernas de grande porte com características diferenciadas, uma localizada na cidade de Santa Cruz do Sul e a outra no município de Vale Real. Ambas desenvolvem-se aproximadamente em um plano horizontal, estendem-se dezenas de metros para o interior das respectivas elevações e não apresentam sinais de drenagens subterrâneas presentes ou passadas. Nas suas morfologias destacam-se superfícies côncavas nas paredes que sugerem que as cavernas se formaram a partir de um sistema de câmaras elípticas, cada câmara com altura original aproximada de 1,5 m e diâmetro original entre 3,5 e 7 m. As câmaras individuais eram unidas através de túneis relativamente curtos. Estas câmaras estão mais bem preservadas na caverna de Santa Cruz do Sul; a caverna de Vale Real apresenta-se muito desfigurada, tanto por processos inorgânicos como por ação antropogênica. As características gerais das duas cavernas permitem propor que se originaram pela ação de escavação de preguiças gigantes da Megafauna sul-americana. Suas dimensões sugerem que foram escavadas e habitadas não por animais isolados, mas por grupos de preguiças. As paredes originais polidas sugerem que as câmaras foram usadas por longos períodos (séculos). Sua morfologia é tão contrastante com àquela dos sistemas de túneis encontrados na Região Sul do Brasil, também escavados pela Megafauna, que propomos que esta morfologia de abrigo subterrâneo se refere a uma espécie específica de preguiça-gigante, cuja identificação será muito difícil.

Palavras-chave: cavernas, megafauna, preguiças-gigantes, túneis, câmaras, Brasil. 


\section{INTRODUCTION}

In southern Brazil, spanning the states of Rio Grande do Sul and Santa Catarina, hundreds of tunnels that were probably dug by fossorial vertebrates of the Cenozoic Megafauna, such as giant armadillos (Dasypodidae) and ground sloths (Xenarthra) have been found (Bergqvist \& Maciel, 1994; Buchmann et al., 2009; Frank et al., 2012a,b, 2013). The widths and heights of the original tunnels range between 0.7-4.0 and 0.6-2.0 m, respectively. Individual tunnels may reach lengths of more than $50 \mathrm{~m}$. Over $80 \%$ of the tunnels are found completely filled with sediments. Larger outcrops, like anthropogenic cuts with lengths between some tens of meters to a few hundred meters, often show several tunnels side by side; such tunnel clusters may be formed by more than 30 tunnels side by side (Frank et al., 2012a, p. 146). Investigation of occurrences with open tunnels shows that the tunnels form complex systems that can have an added tunnel length exceeding $300 \mathrm{~m}$ (Ruchkys et al., 2014). The regional density of tunnel systems may be of more than a tunnel system per square kilometer, some regions present one or more tunnel systems in every hill. The usual pattern of Cenozoic paleovertebrate tunnels in southern Brazil, therefore, is that the tunnel systems are formed without the presence of chambers. This paper presents the features of two large caves that most probably arose from a different kind of underground structure produced by fossorial Cenozoic paleovertebrates. This other structure is a huge underground shelter composed of a system of large ellipsoidal chambers linked by relatively short and low tunnels.

\section{METHODS}

Several of the huge tunnels dug by fossorial vertebrates of the Cenozoic Megafauna in southern Brazil still remain open today and are well known by the landowners, who visit them sporadically driven by curiosity. Images and descriptions of some of these tunnels can be found even on the internet. Acknowledging this fact, an extensive digital prospecting was performed, looking for images related to terms commonly used for cavities, such as "caves", "grottoes", "holes" and others, focusing the search on occurrences in the state of Rio Grande do Sul. This survey resulted in a list of over 200 identified caves in dozens of municipalities. Most caves are shallow rock shelters, overhangs or other kinds of cavities located on steep rock walls or behind waterfalls, others were formed by rocky landslides or by creeks or rivers through hydraulic action - all these are unrelated to fossorial paleovertebrates. Using the available information, two caves with different characteristics were selected. One is located in an urban park in the city of Santa Cruz do Sul and the other in the municipality of Vale Real (Figure 1). Both seemed to extend deep into hills constituted by sandstones, were not located on more or less vertical cliffs and are not associated to running water (behind waterfalls, besides a creek or river, etc.).

To begin, both caves were inspected and photographed, discussing its characteristics with the team. Once the caves were confirmed as potentially of fossorial paleovertebrate origin, detailed photographic surveys of the morphology of the caves and of the features on the walls were performed,

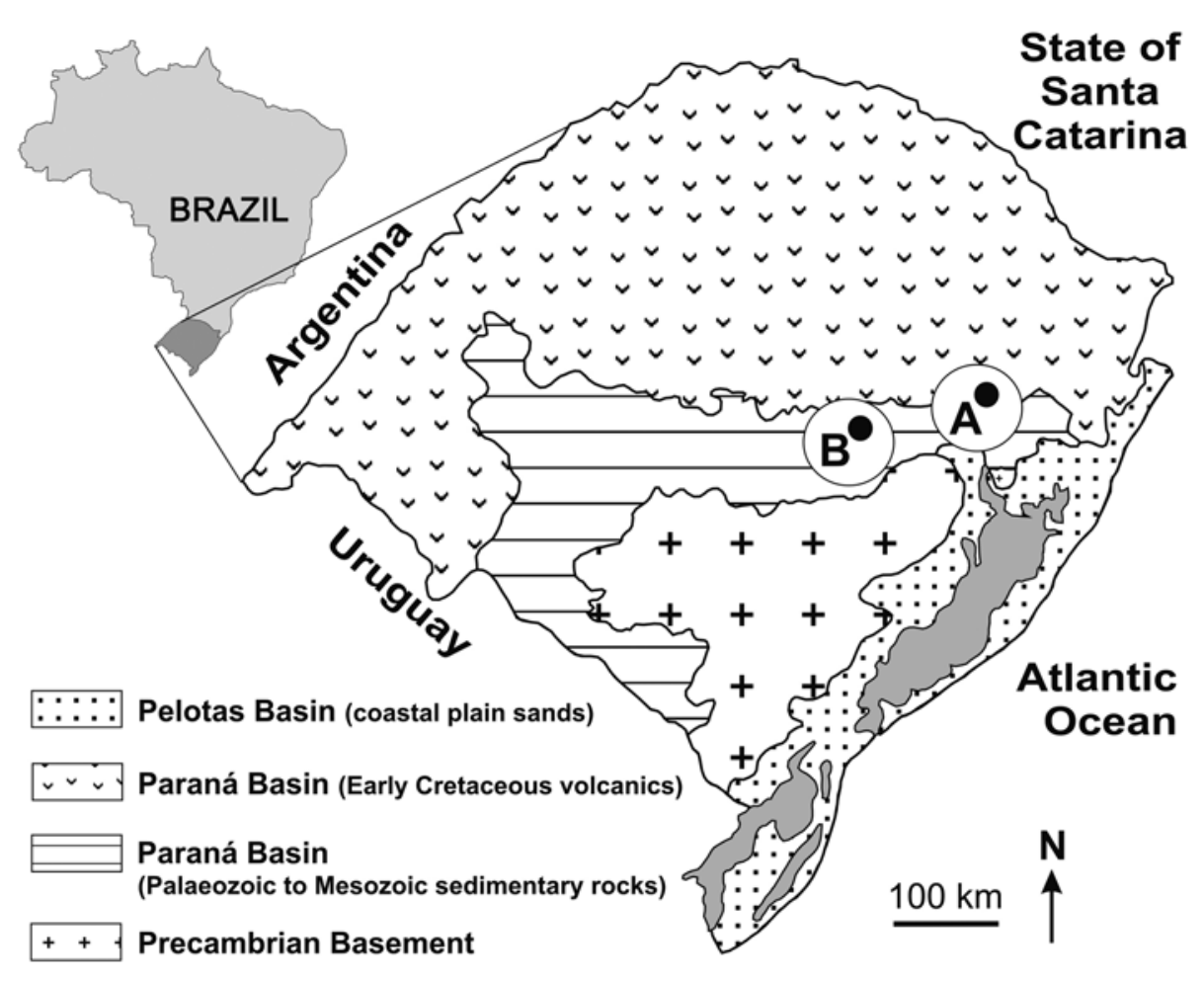

Figure 1. Location of the caves and geological outline of the region. A, Vale Real cave; B, Santa Cruz do Sul cave. 
focusing the search on still existing original characteristics. Using a theodolite and related topographic equipment, we made planimetric surveys of the caves. Details about the appearances of these two caves over more than half a century ago were obtained through interviews with older locals who had visited the caves for a long time. For both caves, petrographic thin sections were made from the caves' host rock.

\section{GEOLOGY}

Most land in the three southernmost Brazilian states is located in the Upper Ordovician to Cretaceous Paraná Basin (Figure 1). This intracratonic basin comprises an area of more than $1.10^{6} \mathrm{~km}^{2}$ (Zalán et al., 1990; Milani et al., 1998) and is filled with a lower sequence of sedimentary rocks and an upper sequence of volcanic rocks. The volcanic rocks constitute the Lower Cretaceous Serra Geral Formation, part of the ParanáEtendeka Continental Flood Basalt Province (Peate, 1997). The youngest sedimentary formation, immediately beneath the volcanic rocks, is the Late Jurassic - Early Cretaceous Botucatu Formation (Scherer, 2000), whose most prominent lithotype is a fine- to coarse-grained reddish sandstone with large scale aeolian cross-bedding, a relict of a $>1.5$ million $\mathrm{km}^{2}$ arid continental area that extended beyond the limits of the basin. Both caves described in this paper were excavated in this sandstone which, because of its generally medium lithification degree and high stability, was a preferred host rock for paleovertebrate tunnels in this region. The petrographic data of sandstone samples from both caves is listed in Table 1 and the similarities between the caves are shown in Table 2 .

\section{DESCRIPTION}

\section{Vale Real Cave}

The Vale Real cave is located in the rural area of the municipality of Vale Real ( $\left.29^{\circ} 20^{\prime} 24.40^{\prime \prime} \mathrm{S}, 51^{\circ} 13^{\prime} 29.70^{\prime \prime} \mathrm{W}\right)$ (Figure 1), in a private estate. It is known as the "Cave of the Indians". Inscriptions on the walls show that the cave has been visited by European settlers since at least 1878 . The description of the cave, presented below, addresses (i) its size and general characteristics, (ii) the internal morphology and (iii) the characteristics of the lateral walls and of the ceiling.

The cave has an arc-shaped entrance with a width and height of 8 and $2.6 \mathrm{~m}$, respectively (Figure 2A). In the front of the cave entrance there is a flat area with a length of 9.5 $\mathrm{m}$ perpendicular to the entrance. According to reports of old residents in the region, this area was produced by the deposition of sediments taken from inside the cave by treasure hunters, who excavated some parts of the floor and some walls between 2007 and 2009. The length of the cave, measured perpendicular to the slope of the hill, is of $36 \mathrm{~m}$, but its linear development is almost $55 \mathrm{~m}$ with a very irregular perimeter

Table 1. Petrographic data of the sandstone that hosts both caves.

\begin{tabular}{ccc}
\hline & Vale Real & Santa Cruz do Sul \\
\hline Sand size & fine (average $0,1-0,2)$ & fine (average 0,1$)$ \\
Selection & medium & medium \\
Composition & quartz $(>80 \%)$, feldspar & $(>90 \%)$, feldspar \\
Roundness & good & good \\
Sphericity & average to good & average to good \\
Grain contacts & $15-20 \%$ & $20-30 \%$ \\
Porosity & $>60 \%$ of the grains & $>90 \%$ of the grains \\
Iron oxide films &
\end{tabular}

Table 2. Similarities between the caves of Santa Cruz do Sul and Vale Real.

\begin{tabular}{|c|c|c|}
\hline & Santa Cruz do Sul & Vale Real \\
\hline Host rock & Botucatu sandstone & Botucatu sandstone \\
\hline Distance to the nearest stream & $<100 \mathrm{~m}$ & $\sim 200 \mathrm{~m}$ \\
\hline Position of the cave & almost horizontal & almost horizontal \\
\hline Approximate area $\left(\mathrm{m}^{2}\right)$ & 332 & 480 \\
\hline Approximate volume $\left(\mathrm{m}^{3}\right)$ & $600-650$ & 1000 \\
\hline Depth perpendicular to hillside & $28,5 \mathrm{~m}$ & $36 \mathrm{~m}$ \\
\hline Approximate total length & $\sim 50 \mathrm{~m}$ & $\sim 55 \mathrm{~m}$ \\
\hline Defined ellipsoidal spaces & $>6$ & $>6$ \\
\hline Features of groundwater flow & almost none & almost none \\
\hline Collapsing features on the roof & abundant & abundant \\
\hline Original surfaces on the walls & $>6$ & $>4$ \\
\hline Original surfaces on the roof & 1 & 1 \\
\hline Evidence of buried portions & several & several \\
\hline
\end{tabular}




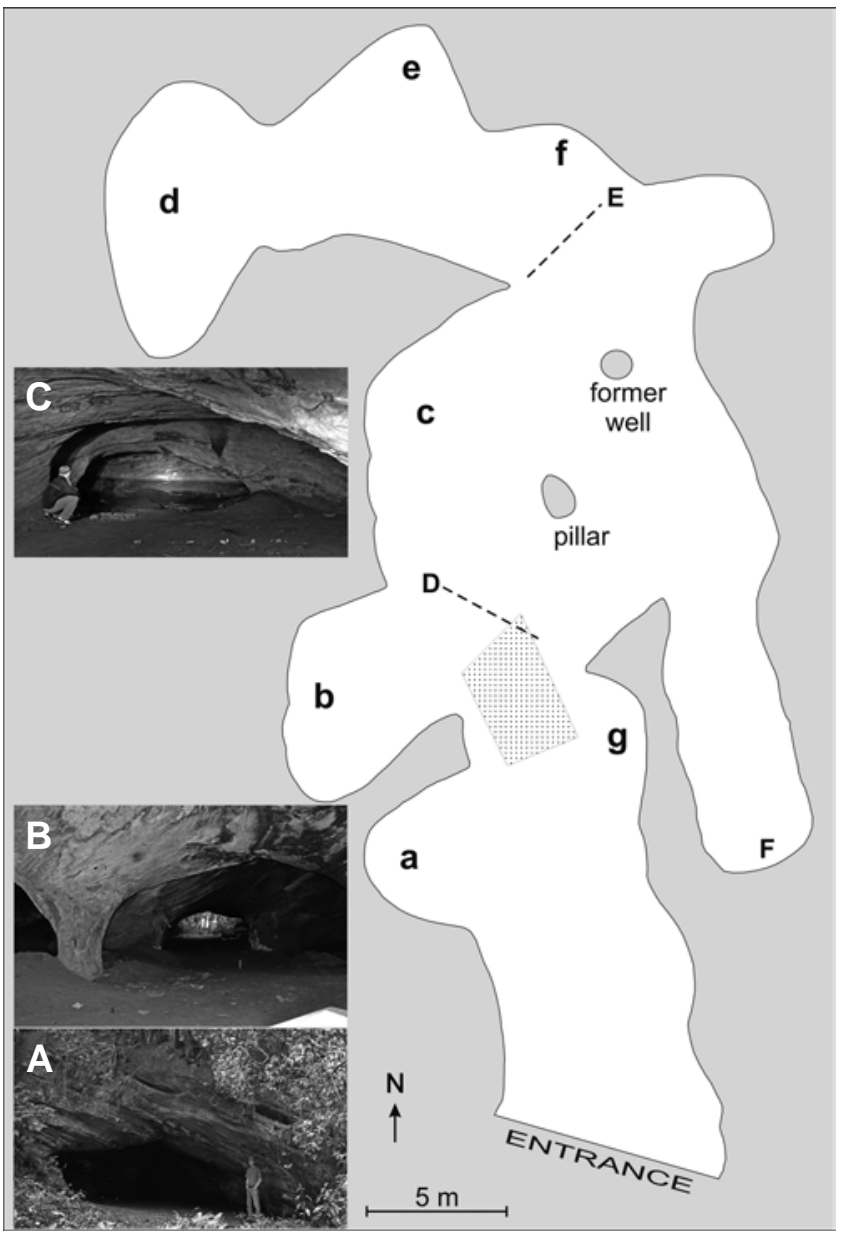

Figure 2. Floorplan of the Vale Real cave. A, entrance of the cave (observer $=1.84 \mathrm{~m}$ ); $\mathbf{B}$, view from c (see plan) towards the entrance (on the left, around the pillar, the excavations of the treasure hunters can be seen); C, view from $\mathrm{E}$ towards $\mathrm{d}$. Lowercase corresponds to concave surfaces.

(Figures 2B,C). The cave has an area of approximately $480 \mathrm{~m}^{2}$ and a volume of around $1,000.00 \mathrm{~m}^{3}$. The floor is developed on three levels: an initial part (Figure 2: from the entrance to the dashed line) is almost horizontal at the same level as the flat area in front of the cave entrance. A middle portion (Figure 2: between "D" and "E") is slightly ascending and a last level (Figure 2: from "E" until the end of the cave) is slightly descending. The maximum gap between the entrance of the cave and the highest point of the floor (Figure 2: near to "E") is approximately $1 \mathrm{~m}$.

Today, the heights of the cave vary between zero and nearly $3.5 \mathrm{~m}$. The area between the pillar and points "E" and "F" (Figure 2) has had its floor and some parts of the wall intensely excavated by treasure hunters. Longtime residents of the regions all agree that there was a "well" (a hole with water) inside the cave (at the position shown in Figure 2), with a diameter of 60-70 $\mathrm{cm}$ and of unknown depth. This well was filled with sand by the treasure hunters. On 2 spots (Figure 2: "a" and "d") there are cracks and cavities of different sizes (maximum axis of less then $40 \mathrm{~cm}$ ) at the upper part of the wall, forming an alignment that coincides with the plane of the cross-bedded strata of sandstone that hosts the cave (Figure 3C). In the last chamber of the cave (Figures 2C, 4D), the lower part of the wall is covered with a black coating from the floor up to a height of approximately $50 \mathrm{~cm}$. The roof of the cave and some of the upper portions of the lateral walls also exhibit dark colors, contrasting with the lighter colored portions of the walls where collapsing has occurred, which exposed the original red and pink color of the sandstone. Approximately six spots have white millimeter-thick coatings, which may be considered speleothems (Figure 4a). Together, these spots cover less than $20 \mathrm{~m}^{2}$, mainly at the upper limit of the lateral walls and sometimes on the roof.

Despite the anthropogenic activity and several collapsing features (described below), it is possible to recognize, on the lateral walls, several concave surfaces formed by smooth and continuous vertical and horizontal arcs. As a whole, these concave surfaces tend to constitute ellipsoidal spaces, with the two major axes disposed horizontally and the smaller axis vertically. In the rear part of the ellipsoidal spaces, there is no opening or continuation of the cave; they always end up as dead ends (Figure 4). The concave surfaces may be simple or compound. The simple surfaces have a side wall formed by a continuous arc whose curvature may be sharper or gentler. On Figure 2, these concave surfaces are in lowercase and all surfaces except "b" and "c" are simple surfaces. Despite the fact that surface "a" is partially buried, it defines an ellipsoidal space precisely (Figure 4a). The composite surfaces have a lateral wall formed by a succession of several very smooth concave surfaces (Figures $2 \mathrm{~b}, \mathrm{c})$. Each one of these spaces clearly shows three successive concave surfaces which form a larger arc.

The lateral walls and the roof are composed of (i) collapsed surfaces, and (ii) smooth surfaces. The collapsed surfaces are those who show signs of detachment of platy sandstone blocks, exposing the pink original color of the sandstone. Usually, the collapsed surfaces are linked by more or less vertical fracture surfaces (Figure 3A). Much of the lateral walls and virtually the entire cave roof are formed by such surfaces. The platy shape of the blocks was constrained by the large-scale cross-stratification of the sandstone, whose most common attitude is $\mathrm{N} 20^{\circ} \mathrm{W} 20^{\circ} \mathrm{NE}$. The size of the collapsed blocks, considering the largest continuous flat surfaces on the roof, reaches $1.5 \mathrm{~m}$. The smooth surfaces, on the other hand, show a very uniform, smooth and slightly wavy surface. They cover an area of approximately $6 \mathrm{~m}^{2}$ on the roof of the cave (Figure 2: dotted area between " $D$ " and "g"; Figure 3D) and the entire surface of the ellipsoidal spaces indicated "a" and "g". In these spaces, fractured portions show that these smooth surfaces are formed by a layer of sandstone with a more pronounced diagenesis, with a lighter color and a thickness ranging from 1 to $20 \mathrm{~mm}$ (Figure 4h). The west side of the pillar is also formed by a smooth surface with inscriptions dated from 1897 (“Jacob Schmitt”) and from 1898 (in indecipherable gothic German). In front of this side of the pillar, on the wall of concavity "c", the oldest inscriptions are dated from 1904 ("Fredolino Zimmer") and 1907. These inscriptions testify that these walls are original. 

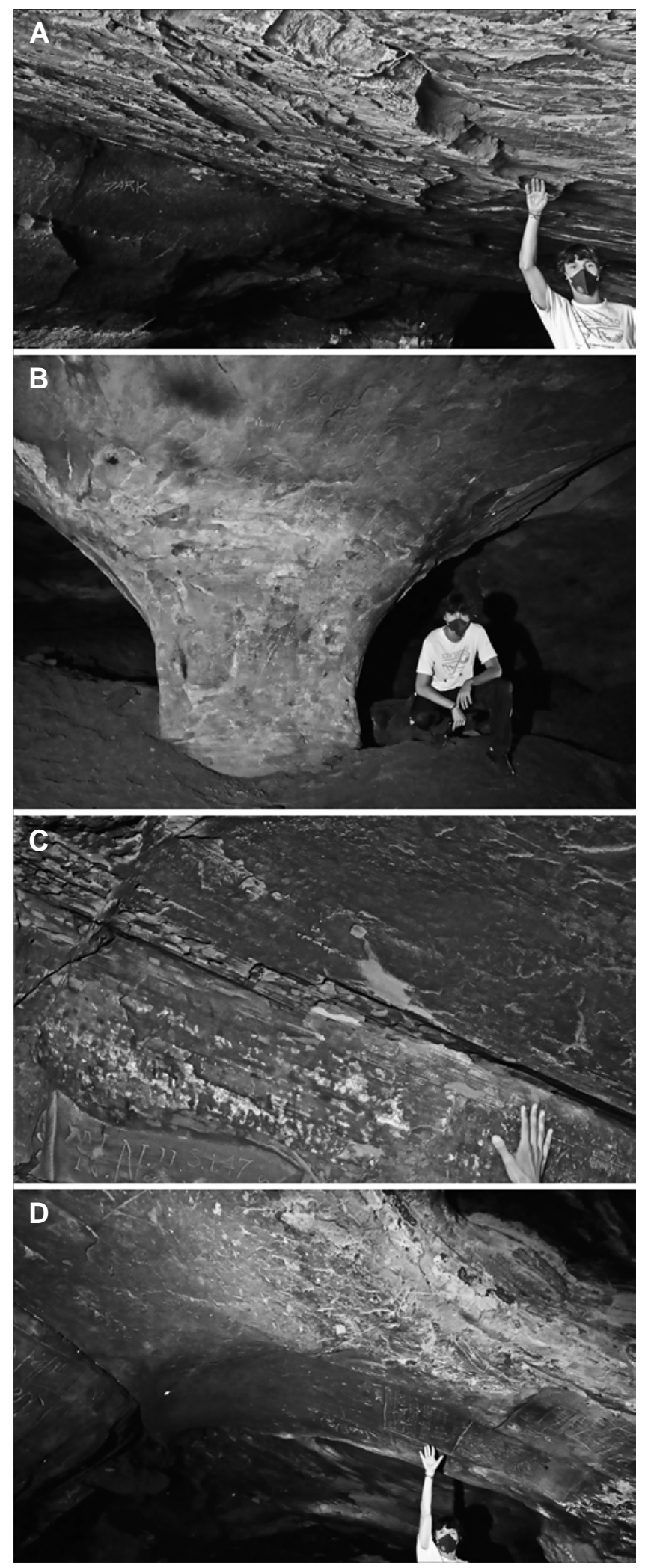

Figure 3. Aspects of the Vale Real cave. A, image of the roof with collapsed surfaces, following the stratification of the sandstone; B, pillar, seen form $\mathrm{W}$ to $\mathrm{E}$. On the floor around the pillar are anthropogenic excavations. On this side of the pillar there is an inscription of 1897 "Jacob Schmitt"; C, opening that coincides with the stratification of the sandstone at the upper part of the ellipsoidal space $1 ; \mathbf{D}$, completely smooth roof, corresponding to the dotted area on Figure 2. View from $\mathrm{S}$ to $\mathrm{N}$.

\section{Santa Cruz do Sul Cave}

This cave, also known as "Cave of the Indians" (portuguese: "Gruta dos Î́ndios"), is located in the "Park of the Cave" ("Parque da Gruta") in the city limits of Santa

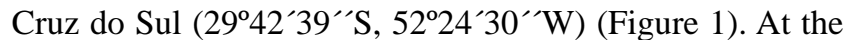
entrance of the cave, which is frequently visited when the Park is open, there is an iron gate with padlock; inside there are several fixtures (Figures 5A,B). The cave extends for $28.5 \mathrm{~m}$ perpendicular to the slope of the hill, comprising an area of approximately $332 \mathrm{~m}^{2}$ and a volume between 600 and $650 \mathrm{~m}^{3}$.

Through a morphological analysis the cave can be subdivided into two spaces of approximately equal length, but with markedly different states of conservation regarding the original morphology and the surface structures of the walls: the front space and the distal space, divided by the dashed line $\mathrm{C}^{-} \mathrm{C}^{\prime}$ in Figure 5.

The front space forms an approximately linear, NE-SW oriented cavity whose widths range between 5 and $8 \mathrm{~m}$. Its height varies from virtually zero at its NE edges to more than $3 \mathrm{~m}$ near the cave entrance. The arrangement of the walls is very irregular and does not reveal any recognizable pattern (Figure 5B). The walls show many fractures and collapsing surfaces, which can be roughly perpendicular or parallel to the large-scale cross-bedding of the sandstone who hosts the cave. Close to the cave entrance (Figure 5; point "D"), the roof is much higher, like a dome, following an almost vertical fracture in the sandstone. Similar collapsing features, but on a smaller scale, can be seen on the entire length of the walls and the roof. According to information provided by older citizens, decades ago the government undertook extensive excavations in the cave in order to facilitate the access to the public. During this work, the large fallen blocks were removed from the cave, resulting in the current height of the floor and the roof. These citizens also reported that some archeological excavations were conducted in the cave in search of Indian artifacts, but nothing was found. Due to these intense anthropogenic interventions, neither the current dimensions, nor the surface of the walls and of the floor of this front space can be considered original, and the current situation does not allow any conclusion about its original morphology. Moreover, all the walls and the entire roof, with the exception of the highest and most inaccessible portions, have been scratched or painted with names and dates. The oldest date back to more than half a century ago.

The distal space shows a well-defined morphology. All of its lateral walls are formed by successive concave surfaces with a remarkable uniformity in the degree of concavity (Figures 6A,B). These surfaces are not only vertically concave, but also horizontally; concave surfaces on opposite walls create several ellipsoidal spaces whose longer axes are always horizontal, but of different lengths. The vertical axis of the ellipsoidal spaces, considering the vertical arch formed by several of the analyzed concave surfaces, has a length of around $1.5 \mathrm{~m}$. The best-preserved ellipsoidal space is located at the rear end of the cave (Figures 5F, 6A). Ten individual concave surfaces were identified (Figure 5: lowercase), all of them with their base at approximately the same horizontal 

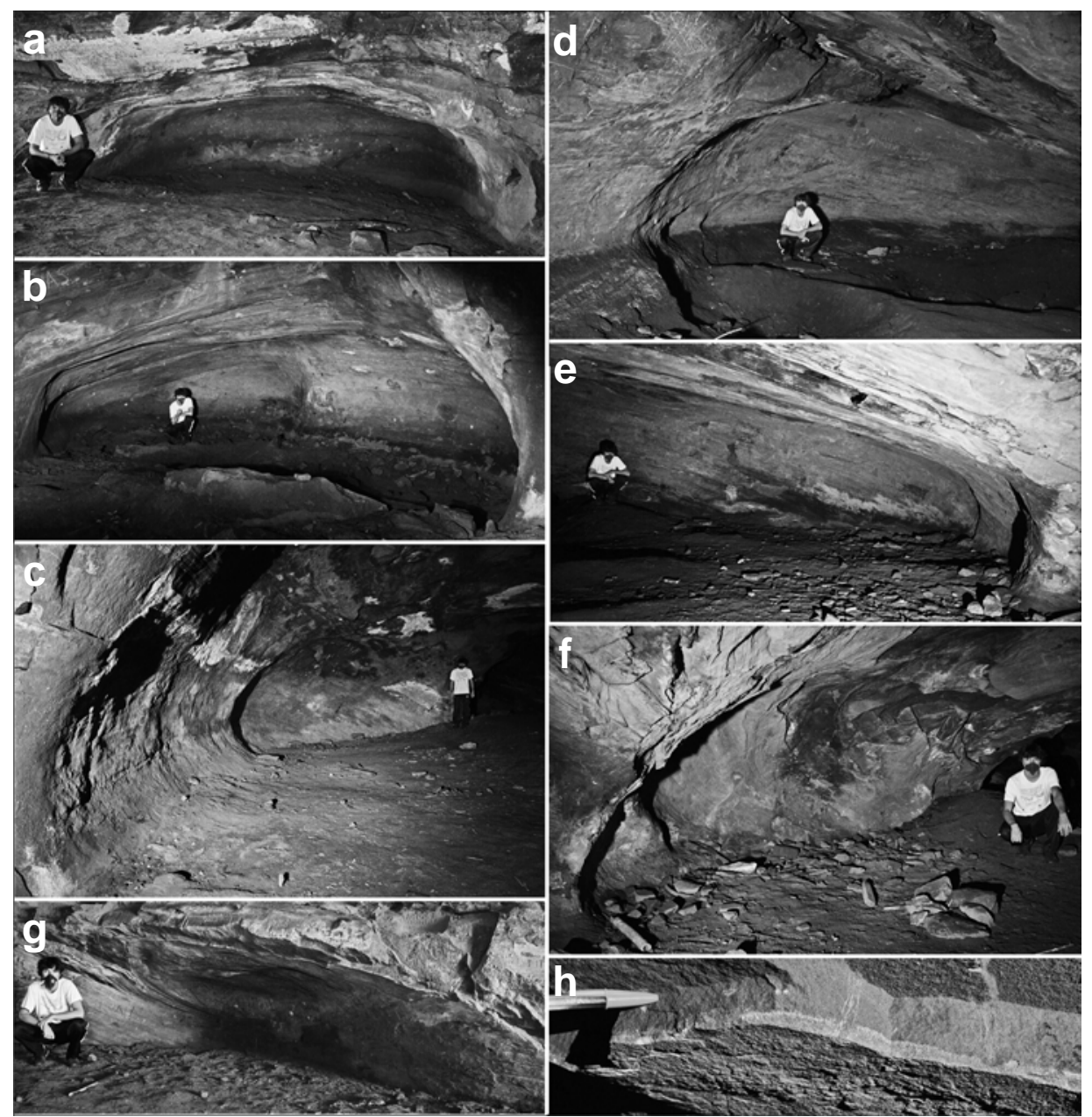

Figure 4. Ellipsoidal spaces in the Vale Real cave; the lowercase corresponds to those of Figure 2 and the text (observer $=1.75 \mathrm{~m}$ ). Image " $\mathrm{m}$ " shows in detail the whitish centimetric crust of more lithified sandstone that forms the smooth surface of the ellipsoidal space " $\mathrm{g}$ ". Pen cap $=5.6 \mathrm{~cm}$.

plane. The roof of the cave in the distal space shows several collapsing features, but much less pronounced than those in the front space. At a single point on the roof (Figure 5: dotted area; Figure 6E) there is a continuous, very smooth, slightly concave surface similar to those at the lateral walls, without any collapsing features. The superposition of two concave surfaces (Figures $5 g-h$ ), also occurs there, with the lower one buried with sediments by more than $60 \%$. When the lower concave surface (Figure $5 \mathrm{~g}$ ) is combined with the opposite one (Figures $5 \mathrm{j}$ ), also buried by at least $50 \%$, it is possible to define an ellipsoidal space located at a level some $50 \mathrm{~cm}$ below those of the concave surfaces from "a” to "f”. The wall surfaces and most of the roof also are covered by scratchings left by the visitors of the cave.

The surfaces of the walls are either fractured or smooth. The fractured surfaces may be concordant or discordant with the large-scale cross-bedding of the sandstone and expose the sandstone with its original pinkish color. They are found mostly on the roof of the cave and are much less abundant than in the front space of the cave.

The smooth surfaces are those of the concave surfaces and have a whitish-brown color. They are extremely uniform and smooth, almost polished, and have only some irregular grooves. In a single point there are some broad grooves, roughly parallel, near the roof of the cave (Figure 6C). These smooth surfaces show a brown crust with a slightly irregular thickness between 1 and $5 \mathrm{~mm}$, sometimes very well exposed at fracture surfaces (Figure 6D). Petrographical analysis of the crust revealed a composition of a cryptocrystalline brownishreddish material who shows many orange internal reflections with crossed polarizers on reflected light microscopy, suggesting the presence of goethite (hydrated iron oxide phases). Under this crust there is a black film with a thickness of less than 1 millimeter covering the reddish sandstone.

\section{DISCUSSION}

The nature of the discussion about the origin of these two caves is much more speleological than palaeontological. What evidences or traces do these caves display that point to the processes, factors or characters that generated them?

The most common origins of caves can be quickly excluded for this case study. The two caves were not formed by the dissolution of the host rock as solutional caves in 


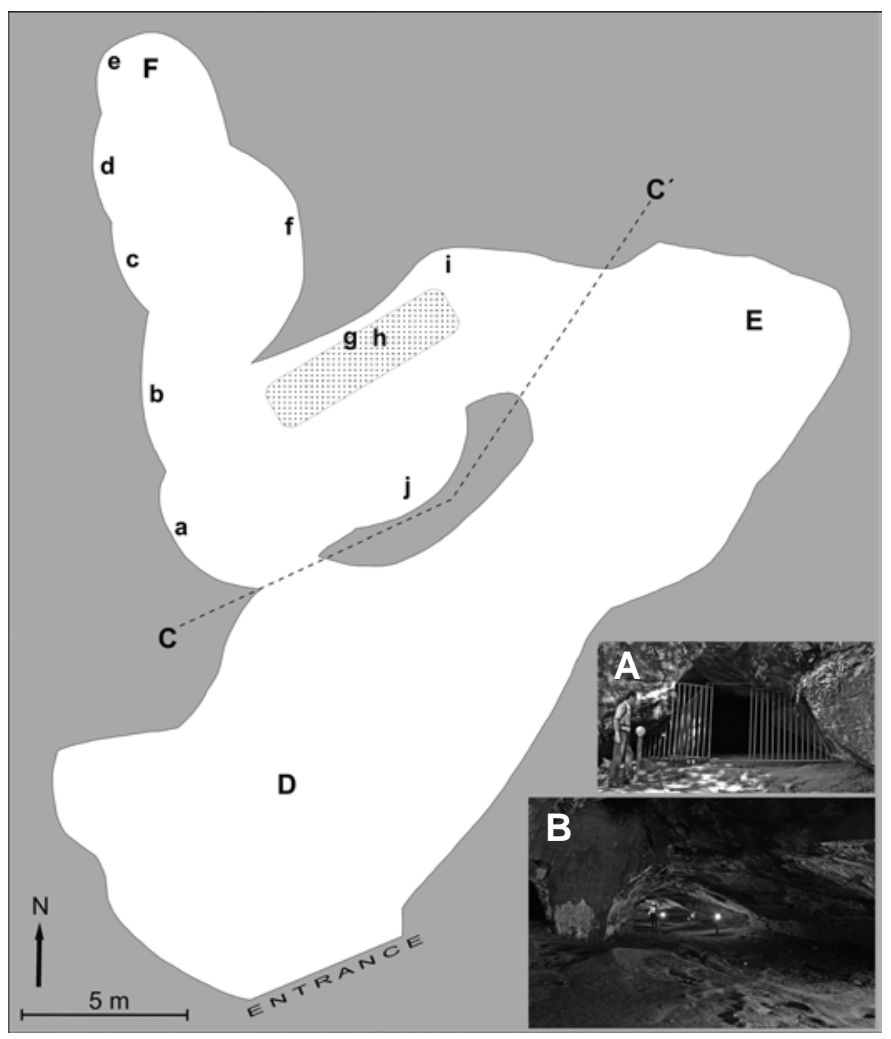

Figure 5. Floor plan of the Santa Cruz do Sul cave. A, entrance of the cave (observer $=1.85 \mathrm{~m}$ ); $\mathbf{B}$, view from D (see floor plan) towards $\mathrm{E}$ (observer $=1.8 \mathrm{~m}$ ). The $\mathrm{C}-\mathrm{C}^{\prime}$ ' line divides the front space from the distal space. Lowercase from "a" to " $\mathrm{j}$ " are concave surfaces; $\mathrm{F}$ indicates the position of the best-preserved ellipsoidal space (chamber) and the dotted area indicates the position of the still original roof (see text).

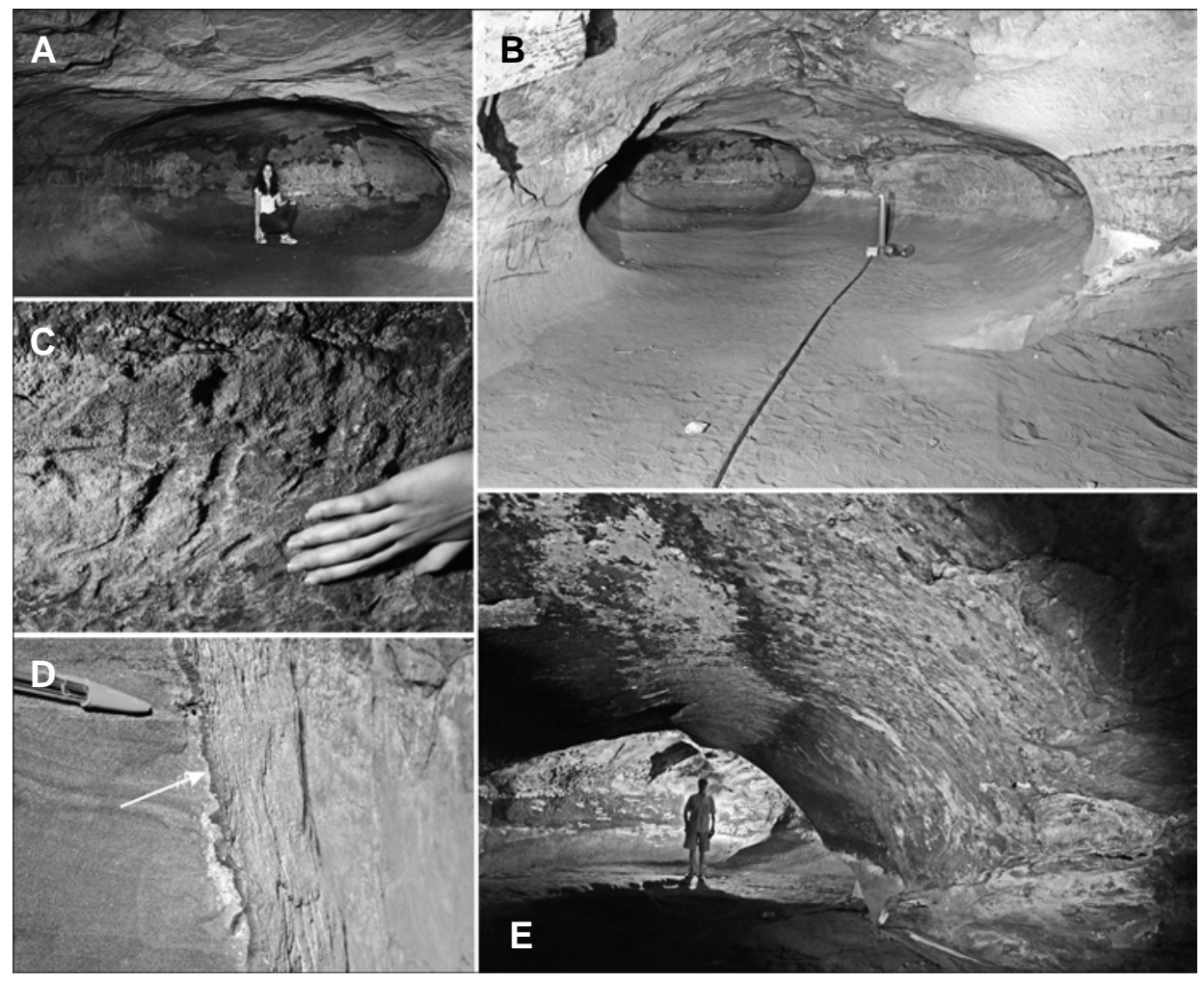

Figure 6. Aspects of the Santa Cruz do Sul cave. A, Concave surface "e" (Figure 5), defining the ellipsoidal space $F$ at the rear end of the cave; $\mathbf{B}$, succession of concave and smooth surfaces on opposite walls of the cave, defining several ellipsoidal spaces. On the roof there are many fracture surfaces. Height of the luminaire $=80 \mathrm{~cm}$; C, large parallel grooves near the roof of the cave, on an original concave surface D, irregular, dark, centimetric crust (arrow) of a concave surface on a fracture located on the intersection of concave surface "a" (Figure 5) with line $\mathrm{C}^{-\mathrm{C}^{\prime}}$. The smooth surface is on the right; E: concave, continuous, smooth and whitish roof (dotted area on Figure 5) (observer = 1.75 m). 
carbonate rock like limestone and dolostone (e.g. Palmer, 1991). Likewise, they were not formed by the action of waves along beaches (abrasion caves or sea caves) (e.g. Waterstrat et al., 2010) nor they are spaces between fallen blocks (talus caves or boulder caves) (e.g. Sjöberg, 1987), cavities inside fault zones (crevice or structural caves) (e.g. Margielewski \& Urban, 2003) or caves related to volcanic activity (lava tubes or lava caves) (e.g. Peterson et al., 1994). Processes like the ones responsible for "granite karst" (e.g. Osborne et al., 2013) and "kamenitza" or "gnamma" (e.g. Goudie, 2013, p. 69) must also be excluded. Caves of anthropogenic origin (e.g. Kostof, 1989; Wimmer, 2000) generally display a unique set of features: usually the walls are vertical, the roofs horizontal, the corridors have a rectangular section and the chambers (rooms) are square or rectangular. Since they were excavated in relatively friable rocks, one can easily recognize on the walls the marks of the tools used during the excavation, such as hatchets, pickaxes and hoes. In the same way, the irregular subterranean spaces left by mining activity also display numerous features and artifacts related to the extraction of the ore. Furthermore, it should be noted that the indigenous people who populated the Brazilian territory in pre-colonial times did not know metallic artifacts, using only stones, pottery and utensils made from wood (Prous, 1992). With these instruments, the excavation of sandstones with an advanced degree of lithification, such as the sandstones of the Botucatu Formation, is virtually impossible. As such, the origin of the two herein presented caves as excavations by pre-colonial people can be discarded. Recent (post-colonial) antrophogenic action may be destructive or not. Destructive action usually is due to treasure hunters, who dig the ground, work the walls with tools and leave tool marks everywhere (Figure 7A). Caves adapted for religious use (most often as grottos of Our Lady of Lourdes) generally have their floor leveled, fallen blocks have been removed and the entrance was cleared (Figure 7B).

Worldwide, caves in quartz sandstones are very common and so they are in the quartz sandstones of the Botucatu Formation, in which small caves with a volume of up to a few cubic meters are easily found. Most are located on more or less vertical cliffs that are currently exposed to sun, rain and wind and some of them, in past times, maybe to surficial drainage. Dozens of such caves have been spotted by our team during the search for paleomammal tunnels. These small cavities have an irregular morphology (roughly spherical, cylindrical or conical), extend at maximum two or three meters inside the hills and are not related to flowing underground waters or to paleovertebrates. Usually it is very difficult to identify traces that allow conclusive statements about their origin, but most probably the above-cited factors must have been responsible. These small caves and other hollows in sandstone with obvious different genesis (talus and crevice caves, large overhangs, cavities behind waterfalls, etc.) need not to be discussed here.

To pinpoint the differences between large caves of inorganic origin in quartz sandstone and the ones related to paleovertebrates, we will discuss first the inorganic caveforming processes and the characteristics of the caves thus formed and, in a second moment, highlight the evidences that indicate that the two above-described caves were produced by paleomammals. Features of both types of caves are compared in Table 3.

Big-sized caves in quartz sandstones are formed by a set of processes recognized only in recent decades. These processes closely resemble the cave-forming ones operating in carbonate rock (e.g. Wray, 2009; Sauro, 2014). To form a cave in quartz sandstone, the first step is the dissolution of quartz by waters that infiltrate along intergranular boundaries, bedding planes, joints, microfissures and other weaknesses of the rock (Jennings, 1983; Wray, 1995, 1997). The same process acts in quartzites (e.g. Briceño \& Schubert, 1990). Due to this essential precursor cave-forming process, such caves are termed "solutional caves". Not only is the siliceous cement removed from the rock, but also silica from the sand grains, etching the surface of the grains and loosening them, turning the rock poorly cemented (e.g. Wray, 2009; Figure 8). This process was termed "arenisation" by Martini (1979). Once arenised, the now friable sandstone breaks down easily and can be mechanically removed by flowing underground waters. After opening the first passages, the water flow widens these pathways forming roughly circular sub-horizontal tubes or conduits ("karst tubes"), whose diameters range from a few
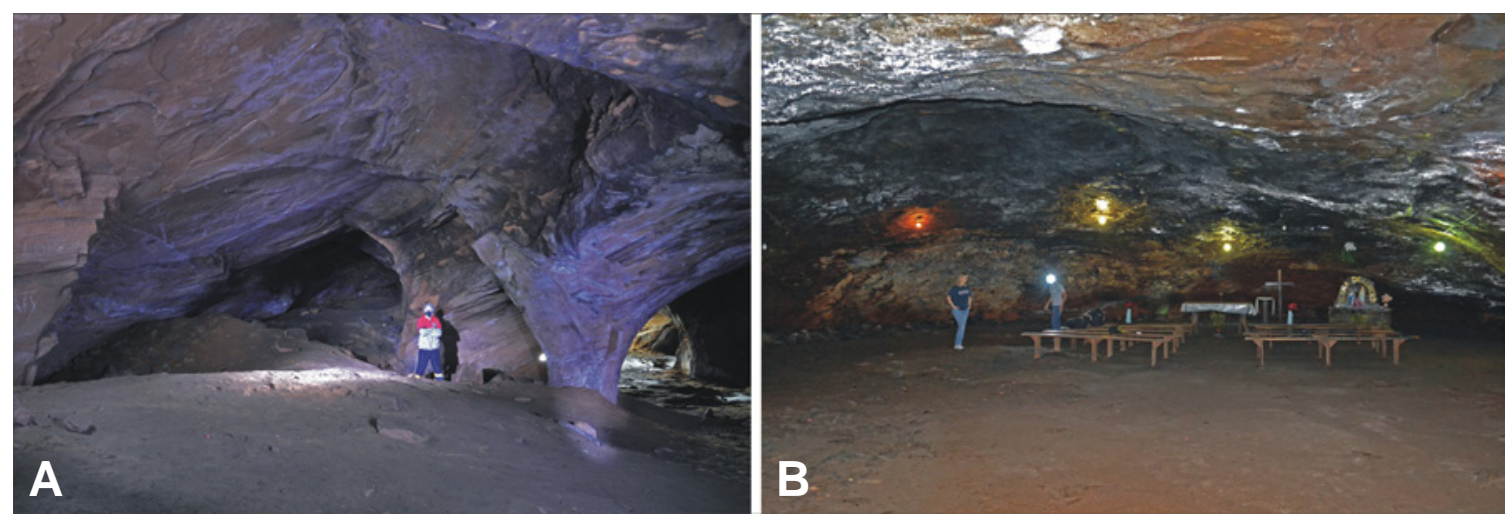

Figure 7. Recent (post-colonial) anthropogenic action in caves. A, excavations (to the left of the person) on the floor and lateral walls made by treasure hunters in the Vale Real cave (seen from "E" to "F" of Figure 2) (observer = $1.72 \mathrm{~m}$ ); B, adaptations made to fit a cave in volcanic rock for religious use (Grotto of Our Lady of Lourdes in the municipality of Santa Tereza, Rio Grande do Sul, Brazil) (left person = $1.75 \mathrm{~m}$ ). 
Table 3. Characteristics of large caves in quartz-sandstones produced by underground waters compared to caves dug by fossorial mammals of the Cenozoic Megafauna in South America.

\begin{tabular}{|c|c|c|}
\hline & Caves of inorganic origin & Paleomammal burrows \\
\hline Network of subsurface drainage conduits or tubes $(\varnothing=2-150 \mathrm{~cm})$ & Very common & Absent or very discrete \\
\hline Seeping waters entering the cave through roof and lateral walls & Very common to absent & Very common to absent \\
\hline Speleothems (many different forms, tens of different minerals) & Absent to common & Absent to very discrete \\
\hline Entering flowing waters at the rear end and along the lateral walls of the cave & Common to absent & Absent \\
\hline Leaving flowing waters at the front end of the cave & $\begin{array}{l}\text { Sometimes absent, usually } \\
\text { present in large amounts }\end{array}$ & $\begin{array}{l}\text { Absent to present in } \\
\text { small amounts }\end{array}$ \\
\hline Features of current or past water drainages, like incised channels & Always present & Absent to discrete \\
\hline Declivity of the cave as a whole & Slight to strong & None to slight \\
\hline Influence of the structural pattern of the rock on cave morphology & Strong & Absent \\
\hline Influence of bedding planes and lithological contacts of the rock on cave morphology & Strong & Absent \\
\hline Waters flowing from the cave into current drainages (creeks, etc.) & Very common to absent & Rare to absent \\
\hline Smooth, almost polished roof and lateral walls & Absent & Common to absent \\
\hline Concave lateral walls & Rare to absent & Common \\
\hline Digging scratches on the roof and the lateral walls & Absent & Common to absent \\
\hline Vertical parallel grooves on the lateral walls due to seeping waters from the walls & Common to absent & Common to absent \\
\hline Collapsing features, especially on the roof & Widespread & Generally less developed \\
\hline Associated surficial typical karst forms & Absent to widespread & Absent \\
\hline
\end{tabular}

centimeters up to $1.5 \mathrm{~m}$ (Wray, 1995, 2009). Such tubes may constitute a regional phenomenon (Wray, 2009), but in our survey we have found only some isolated ones and a single occurrence with well-developed tubes forming a network at the base of a sandstone cliff (Pasqualon et al., 2013). Lateral and vertical collapsing of the sandstone along the tubes widens these conduits, then the fallen blocks disintegrate and the loose sand is removed by the water, resulting in big-sized caves that most often have an active water flow ("stream caves"). Water flow also occurs through discontinuities (joints, fissures, etc.) and following the primary structures of the rock (bedding planes, etc.), opening these features and promoting the collapsing of blocks. Therefore, this kind of caves generally has highly asymmetric shapes that depend on the lithological contacts, bedding planes and structural pattern of the rocks (see Brazilian examples by Wernick et al., 1973, 1977; Monteiro \& Ribeiro, 2001; Spoladore \& Cottas, 2005; Robaina \& Bazzan, 2008; Hardt et al., 2009). If dry, they show very distinctive features of past drainages. More or less common are features like incised channels and tunnel-like lateral caves that constitute outlets similar to soil pipes (Gunn, 2004). As a whole, superficial features (grikes, drainage runnels, solutional basins, solution noches and dolines) and underground features (caves, etc.) closely resemble carbonate karst and, therefore, this is also called "karst” (e.g. Shade, 2002; Self \& Mullan, 2005). As a rule, caves with this origin are easily recognized as unrelated to the digging action of paleovertebrates.

The hypothesis that the caves were initially excavated by mammals of the Cenozoic Megafauna is supported by several features of the caves. The most important is the morphology of the original chambers and walls. Both have to be distinguished from a much larger number of surfaces that formed later due to the collapsing of the walls and roofs, anthropogenic diggings, the entry of subsurface waters, scratchings of cave visitors, and other destruction features. Original features are rare, especially in the Vale Real cave. In this cave the existence of ellipsoidal spaces defined by concave surfaces ("chambers") is an important clue, combined with the absence of any features related to a different genetic process. Original walls have been found there only on a few of the concave surfaces and on a single spot on the roof. These original features are represented by smooth walls. Such smooth, almost polished walls have been found in several paleomammal tunnels excavated in sandstones, and are most likely the result of the rubbing of the hairy back of the ground sloths against the walls and roof during the long-term (centuries or more) usage of the tunnels by many generations of animals (see Frank et al., 2012b, figs. 3C, E; Frank et al., 2013, fig. 9C). This explains the absence of digging scratches, which were erased by this rubbing. Only sometimes, some scratches stay preserved on a few concave spots of the walls (Frank et al., 2012b, fig. 12A). The original smooth surfaces in the Vale Real cave are usually of a much darker color than the surfaces formed by collapsing features, and, when ruptured, these surfaces reveal that they are formed by a distinctive centimetric layer of sand with a different color and lithification degree (Figure 4h). When combined, the concave surfaces with smooth walls constitute ellipsoidal spaces that were buried by up to $50 \%$ in sand and fallen blocks in this cave. Similar considerations apply to the Santa Cruz do Sul cave. The front half of this cave was so thoroughly destroyed to suit the cave for visitors that no original features were left. On a single spot (to the right of the letter " $E$ " in Figure 5) there seems to remain a segment of a tunnel, but it is almost completely filled with sand and rock fragments and it was not excavated by our team. The rear half of the cave, on the other hand, shows very well preserved concave surfaces that outline several defined ellipsoidal spaces. The 


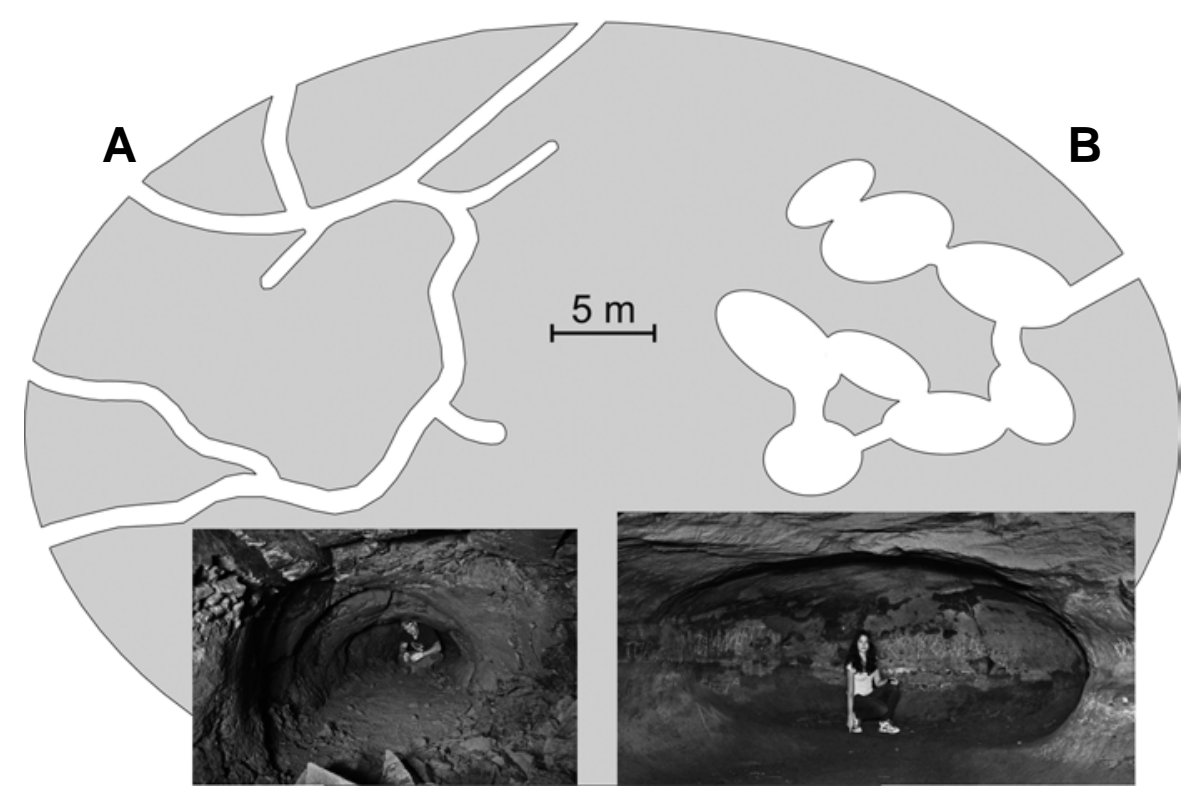

Figure 8. Tunnel-based systems and chamber-based systems. A, schematic hypothetic floorplan of a tunnel-based system, with some longer tunnels connected to shorter ones, several dead-end tunnels and several entrances. Image, tunnel in the city of Erechim; B, schematic hypothetic floorplan of a chamber-based system, with several ellipsoidal spaces connected, when necessary, by short tunnels. The system has only one entrance. Image, last chamber in the Santa Cruz do Sul cave. Scale applies to both systems.

uniformity of sizes of these spaces, with original heights of approximately $1.5 \mathrm{~m}$ and the testimony of older people about the former existence of low tunnels connecting the spaces, are a strong indication of an origin related to fossorial mammals. The few scratches found on the walls (Figure 6C) are not well preserved, as expected, and cannot reinforce the hypothesis. In this cave there is also a roof segment that is smooth and dark, being original (Figure 6E).

Other clues regarding the origin of both caves as paleomammal diggings arise from the analysis of other aspects, the host rock being an important one. Several hundreds of typical fossorial paleomammal tunnels have been found excavated in the sandstones of the Botucatu Formation, showing that the animals were able to dig into this rock despite its toughness (Frank et. al., 2012a,b). The big dimensions of the caves, including the size of the individual ellipsoidal spaces, indicates that the digging animals were not giant armadillos (Dasypodidae), which had a maximum body weight of less than $300 \mathrm{~kg}$ and a body width of no more than $80 \mathrm{~cm}$. The ellipsoidal spaces, with heights of around $1.5 \mathrm{~m}$ or more and horizontal axes exceeding $7 \mathrm{~m}$, are suggestive of fossorial ground sloths (Xenarthra), whose body mass exceeded $800 \mathrm{~kg}$ (Fariña \& Vizcaíno, 1995). The location of both caves, on hillsides close to waterways, follows the pattern of many of these paleomammal tunnels, which always had an entrance directed to a nearby water source (Frank et al., 2012b, p. 153), sometimes being right besides of a waterfall. In Santa Cruz do Sul, for example, the stream that passes in front of the cave is so important regionally that it was used by the first settlers almost a century ago to build the first water reservoir for the emerging city.

In regard of infiltrating (running) ground water in both caves, it is present but in very small amounts, generating small features on only a few spots. Near the roof of concave surfaces "a" and "d" of the Vale Real cave; there are two rows of small voids whose alignment follow the stratification of the sandstone (Figure 4c). These small cavities were most likely formed by infiltrating groundwater, but in such small amounts that the water flow cannot be considered responsible for the genesis of the cave. Similarly, in the Santa Cruz do Sul cave there is an almost vertical fracture in the sandstone near the entry of the cave, through which small amounts of water enter the cave in rainy periods (Figure 5, point $\mathrm{D}$ ). Another feature of most of the caves produced by the action of groundwater is a significant vertical gap between the deepest portion of the cave and the entrance, because of the downward flow of the water. In both caves presented in this paper, however, the cave floor is almost horizontal if we consider the probably original concave surfaces and disregard the anthropogenic interventions.

It is possible that pre-existing smaller caves of inorganic origin were adapted by the fossorial paleomammals to fit their needs. One such situation was described by Carmo et al. (2011). But the present state of both caves does not offer any feature that indicates such an evolution.

As far as this was possible, the reconstruction of the original morphology of both caves suggests a very different pattern if compared to the common burrows of fossorial mammals of the South American megafauna. In Argentina, several contributions analyze burrows from the Cenozoic Megafauna (Imbellone \& Teruggi, 1988; Imbellone et al., 1990; Quintana, 1992; Zárate et al., 1998; Vizcaíno et al., 2001; Isla \& Dondas, 2001), always emphasizing its morphology as shorter or longer tunnels. In Brazil, among hundreds of entirely clogged tunnels and many short open tunnel remnants, some better-preserved tunnel-based 
systems were found, composed of longer (> $20 \mathrm{~m}$ ) tunnels with a width of around $1.4 \mathrm{~m}$ that may be connected to each other by tunnels with similar or smaller diameters, but usually without forming chambers (Frank et al., 2012b, p. 146). Many of these tunnels finish as dead-ends. A single occurrence of these tunnel-based systems has shown a small chamber, with a diameter of $1.6 \mathrm{~m}$ and a height of $0.7 \mathrm{~m}$ (Frank \& Buchmann, 2009). Using the better-preserved distal space of the Santa Cruz do Sul cave as model, we can reconstruct an excavation with a very different morphology: instead of interconnected long tunnels with occasionally small chambers (Figure 8A), we obtain a system of large ellipsoidal chambers connected, when necessary, by short and low tunnels (Figure 8B). Converging chambers in these chamber-based systems may constitute huge caves whose walls are all formed by concave surfaces in several orientations. Since fossorial animals always produce a defined burrow pattern, the strong contrast between the tunnel-based systems and the chamber-based systems suggests that each one applies to a specific fossorial species, most probably to two species of ground sloths because of the huge size of the tunnels and chambers.

When we consider the frequency of both systems, another conclusion seems possible. Regarding the tunnel-based systems, our team has found approximately 1,500 tunnels in the state of Rio Grande do Sul until now. In some regions with favorable rock and relief, each hill seems to host one or more tunnel complexes. The contrast between these very abundant tunnel-based systems and the only two chamberbased systems most probably means that the sloth species responsible for the chambers was much less abundant than the sloth species that excavated the tunnels. Certainly there are tens of thousands of paleomammal excavations still hidden in the hills and mountains, but this contrast in abundance between the two systems found until now will probably be maintained even after more findings in the future.

\section{CONCLUSIONS}

The caves of Santa Cruz do Sul and of Vale Real, which are both large and hosted in sandstone, do not show any evidence of an origin related to underground flowing waters, any other inorganic process or human pre-colonial action. The still original characteristics in both caves had to be identified among a lot of features produced by infiltrating rainwater, collapsing walls and human action, and this search revealed only some smooth walls and smooth parts on the roofs, in addition to a few grooves on the lateral walls that are probably excavation marks. Combining these characteristics with the general original morphology of the caves, especially with the ellipsoidal spaces located at the walls, it is highly probable that both caves were originally underground shelters excavated by fossorial mammals of the Cenozoic megafauna, most probably ground sloths due to the size of the caves.

After more than a century of public access to the caves, with hundreds of visitors every year, it is very unlikely that any direct evidence of the excavators can be found, such as bones, hair or claw fragments. The assignment of the caves to fossorial mammals is also supported by existence of several dozens of better preserved big sized tunnels in both southernmost states of Brazil (Rio Grande do Sul and Santa Catarina) and a great number of smaller tunnels, which show that the fossorial habits of some of the megafauna mammals were commonplace in Southern Brazil during the Cenozoic.

\section{ACKNOWLEDGMENTS}

We are indebted to the team of the city hall of Santa Cruz do Sul for their license to work inside the "Indian Cave" and to L.A. Massochini, whose property hosts the Vale Real cave, for his support during our fieldwork there. Many thanks to V. Krapovickas and to two anonymous referees for their comments that greatly improved the manuscript.

\section{REFERENCES}

Bergqvist, L.P. \& Maciel, L. 1994. Icnofósseis de Mamíferos (Crotovinas) na Planície Costeira do Rio Grande do Sul, Brasil. Anais da Academia Brasileira de Ciências, 66:189-197.

Briceño, H.O. \& Schubert, C. 1990. Geomorphology of the Gran Sabana, Guyana Shield, southeastern Venezuela. Geomorphology, 3:125-141. doi:10.1016/0169-555x(90)90041-n

Buchmann, F.S.C.; Lopes, R.P. \& Caron, F. 2009. Icnofósseis (paleotocas e crotovinas) atribuídos a Mamíferos extintos no Sudeste e Sul do Brasil. Revista Brasileira de Paleontologia, 12:247-256. doi:10.4072/rbp.2009.3.07

Carmo, F.F.; Carmo, F.F.; Buchmann, F.S.C.; Frank, H.T. \& Jacobi, C.M. 2011. Primeiros registros de paleotocas desenvolvidas em formações ferríferas, Minas Gerais, Brasil. In: CONGRESSO BRASILEIRO DE ESPELEOLOGIA, 31, 2011. Resumos, Ponta Grossa, SBE, p. 531-540.

Fariña, R.A. \& Vizcaíno, S.F. 1995. Hace solo diez mil años. $6^{\text {th }}$ ed. Montevideo, Editorial Fin de Siglo, 123 p.

Frank, H.T. \& Buchmann, F.S.C. 2009. A resting chamber in a large palaeovertebrate underground shelter. In: ENCONTRO BRASILEIRO DE ESTUDOS DO CARSTE 2009. Anais, São Carlos, CD-ROM.

Frank, H.T.; Buchmann, F.S.C.; Lima, L.G.; Fornari, M.; Caron, F. \& Lopes, R.P. 2012a. Cenozoic vertebrate tunnels in Southern Brazil. In: R.G. Netto; N.B. Carmona \& F.M.W. Tognoli (eds.) Ichnology of Latin America - selected papers, Porto Alegre, Sociedade Brasileira de Paleontologia, p. 141-157 (Monografias 2).

Frank, H.T.; Lima, L.G.; Gerhard, N.P.; Caron, F.; Buchmann, F.S.C.; Fornari, M. \& Lopes, R.P. 2013. Description and interpretation of Cenozoic vertebrate ichnofossils in Rio Grande do Sul State, Brazil. Revista Brasileira de Paleontologia, 16:83-96. doi:10.4072/rbp.2013.1.0

Frank, H.T.; Oliveira, L.D.; Vicroski, F.N.; Breier, R.; Pasqualon, N.G.; Araújo, T.; Buchmann, F.S.C.; Fornari, M.; Lima, L.G.; Lopes, R.P. \& Caron, F. 2012b. The complex history of a sandstone-hosted cave in the State of Santa Catarina, Brazil. Espeleo-Tema, 23:87-101.

Goudie, A.S. 2013. Arid and semi-arid geomorphology. $1^{\text {st }}$ ed. Cambridge, Cambridge University Press, 461 p. doi:10.1017/ CBO9780511794261

Gunn, J. 2004. Encyclopedia of caves and karst science. New York, Taylor and Francis Group, 1940 p. 
Hardt, R.; Rodet, J.; Pinto, S.A.F. \& Willems, L. 2009. Exemplos brasileiros de carste em arenito: Chapada dos Guimarães (MT) e Serra de Itaqueri (SP). Espeleo-Tema, 20:7-23.

Imbellone, P. \& Teruggi, M. 1988. Sedimentación crotovinica en secuencias cuaternarias bonaerenses. In: REUNIÓN ARGENTINA DE SEDIMENTOLOGIA, 2, 1988. Anais, Salta, ARS, p. 125-129.

Imbellone, P.; Teruggi, M. \& Mormeneo, L. 1990. Crotovinas en sedimentos cuaternarios del partido de La Plata. In: INTERNATIONAL SYMPOSIUM ON LOESS CADINQUA, 1, 1990. Anais, Mar del Plata, p. 166-172.

Isla, F.I. \& Dondas, A. 2001. Facies fluviales del Pleistoceno de Mar Del Plata, Argentina. Revista de la Asociación Geológica Argentina, 56:259-267.

Jennings, J.N. 1983. Sandstone pseudokarst or karst? In: R.W. Young \& G.C. Nanson (eds.) Aspects of Australian sandstone landscapes. Bundanoon, Australian and New Zealand Geomorphology Group, p. 21-30 (Special Publication 1).

Kostof, S. 1989. Caves of god: Cappadocia and its churches. Oxford, Oxford University Press, 350 p.

Margielewski, W. \& Urban, J. 2003. Crevice-type caves as initial forms of rock landslide development in the Flysch Carphatians. Geomorphology, 54:325-338. doi:10.1016/S0169555X(02)00375-6.

Martini, J.E.J. 1979. Karst in black reef quartzite near Kaapsehoop, Easters Transvaal. Annales of the South African Geological Survey, 13:115-128.

Milani, E.J.; Faccini, U.F.; Scherer, C.M.S.; Araújo, L.M. \& Cupertino, J.A. 1998. Sequences and stratigraphic hierarchy of the Paraná Basin (Ordovician to Cretaceous), Southern Brazil. Boletim IG-USP, Série Científica, 29:125-173.

Monteiro, R.C. \& Ribeiro, L.F.B. 2001. Espeleogênese em cavernas areníticas: algumas considerações aplicada à Província Espeleológica da Serra de Itaqueri, Estado de São Paulo, Brasil. In: BRAZILIAN CONGRESS OF SPELEOLOGY, 26, 2001. Anais, SBE, Brasília, p. 138.

Osborne, R.A.L.; Weliange, W.S.; Jayasingha, P.; Dandeniya, A.S.; Algiriya, A.K.P. P. \& Pogson, R.E. 2013. Caves and karst-like features in Proterozoic gneiss and Cambrian granite, Southern and Central Sri Lanka: an introduction. Acta Carsologica, 42:2548. doi:10.3986/ac.v42i1.630

Palmer, A.N. 1991. Origin and morphology of limestone caves. Geological Society of America Bulletin, 103:1-21. doi:10.1130/0016-7606(1991)103<0001:OAMOLC>2.3.CO;2

Pasqualon, N.G.; Frank, H.T.; Silva, M.Y.L.; Althaus, C.E.; Almeida, M.L.; Breier, R.; Oliveira, D.M. \& Bischoff, L. 2013. Pseudopaleotocas em arenitos da Formação Botucatu (JsupKinf): estudo de caso. In: Congresso Brasileiro de Paleontologia, 23, 2013. Boletim de Resumos, Gramado, SBP, p. 311.

Peate, D.W. 1997. The Paraná-Etendeka province. In: J.J. Mahoney \& M. Coffin (eds.) Large igneous provinces. Washington, American Geophysical Union, p. 217-254 (Geophysical Monographs 100).

Peterson, D.W.; Holcomb, R.T.; Tilling, R.I. \& Christiansen, R.L. 1994. Development of lava tubes in the light of observations at Mauna Ulu, Kilauea Volcano, Hawaii. Bulletin of Volcanology, 56:343-360. doi:10.1007/bf00326461

Prous, A. 1992. Arqueologia Brasileira. Brasília, Editora da UnB, $607 \mathrm{p}$.

Quintana, C.A. 1992. Estructura interna de una paleocueva, posiblemente de un Dasypodidae (Mammalia, Edentata) del Pleistoceno de Mar del Plata (Provincia de Buenos Aires, Argentina). Ameghiniana, 29:87-91.
Robaina, L.E.S. \& Bazzan, T. 2008. Feições cársticas em rochas siliciclásticas no Oeste do Estado do Rio Grande do Sul. Revista Brasileira de Geomorfologia, 9:53-64.

Ruchkys, U.A.; Bittencourt, J.S. \& Buchmann, F.S.C. 2014. A paleotoca da Serra do Gandarela e seu potencial como geossítio do Geoparque Quadrilátero Ferrífero, Minas Gerais. Caderno de Geografia, 24:249-263.

Sauro, F. 2014. Structural and lithological guidance on speleogenesis in quartz-sandstone: evidence of the arenisation process. Geomorphology, 226:106-123. doi:10.1016/j. geomorph.2014.07.033

Scherer, C.M.S. 2000. Aeolian dunes of the Botucatu Formation (Cretaceous) in southernmost Brazil: morphology and origin. Sedimentary Geology, 137:63-84. doi:10.1016/S00370738(00)00135-4

Self, C.A. \& Mullan, G.J. 2005. Rapid karst development in an English quartzitic sandstone. Acta Carsiologica, 34:415-424.

Shade, B.L. 2002. The genesis and hydrogeology of a sandstone karst in Pine County, Minnesota. University of Minnesota, Ph.D. thesis, $171 \mathrm{p}$.

Sjöberg, R. 1987. Caves as indicators of neotectonics in Sweden. Zeitschrift für Geomorphologie, 63:141-148.

Spoladore, A. \& Cottas, L.R. 2005. A Gruta do Portão de Cima e a Gruta do Portão de Baixo: duas cavernas areníticas no município de Sengés - PR. Geografia, 14:71-83.

Vizcaíno, S.F.; Zárate, M.; Bargo, S.M. \& Dondas, A. 2001. Pleistocene burrows in the Mar Del Plata area (Argentina) and their probable builders. Acta Palaeontologica Polonica, 46:289-301.

Waterstrat, W.J.; Mylroie, J.E.; Owen, A.M. \& Mylroie, J.R. 2010. Coastal caves in Bahamian eolian calcarenites: differentiating between sea caves and flank margin caves using quantitative morphology. Journal of Cave and Karst Studies, 72:61-74. doi:10.4311/jcks2009es0086.

Wernick, E.; Pastore, E.L. \& Pires Neto, A. 1973. Cavernas em arenito. Notícia Geomorfológica, 13:55-67.

Wernick, E.; Pastore, E.L. \& Pires Neto, A. 1977. Cuevas en areniscas, Rio Claro, Brasil. Boletín de la Sociedad Venezolana de Espeleología, 8:1699-1707.

Wimmer, H. 2000. Die Regional-typisierung der Erdställe. Der Erdstall, 26:54-56.

Wray, R.A.L. 1995. Solutional landforms in quartz sandstones of the Sydney Basin. School of Geosciences (Geography), University of Wollongong, Ph.D. thesis, 381 p.

Wray, R.A.L. 1997. A global review of solutional weathering forms on quartz sandstones. Earth-Science Reviews, 42:137-160. doi:10.1016/s0012-8252(96)00056-6

Wray, R.A.L. 2009. Phreatic drainage conduits within quartz sandstone: evidence from the Jurassic Precipice Sandstone, Carnarvon Range, Queensland, Australia. Geomorphology, 110:203-211. doi:10.1016/j.geomorph.2009.04.007

Zalán, P.V.; Wolff, S.; Conceição, J.C.J.; Marques, A.; Astolfi, M.A.M.; Vieira, I.S.; Appi, V.T. \& Zanotto, O.A. 1990. Bacia do Paraná. In: G.P. Raja Gabaglia; E.J. Milani (eds.) Origem e evolução de bacias sedimentares, Petrobrás/Serec/Cen-Sud, p. 135-168.

Zárate, M.A.; Bargo, M.S.; Vizcaíno, S.F.; Dondas, A. \& Scaglia, O. 1998. Estructuras biogênicas en el Cenozoico tardio de Mar del Plata (Argentina) atribuibles a grandes mamíferos. Revista da Asociación Argentina de Sedimentologia, 5:95-103.

Received in October, 2014; accepted in May, 2015. 